\title{
Efektivitas Penggunaan Aplikasi Quizizz Pada Matakuliah Matematika Sekolah Ditinjau dari Motivasi dan Hasil Belajar Mahasiswa
}

\author{
Rica Wijayanti ${ }^{1}$, Didik Hermanto ${ }^{2}$, Zainudin ${ }^{3}$ \\ 1, 2, 3 Program Studi Pendidikan Matematika, STKIP PGRI Bangkalan, \\ Jl.Soekarno Hatta No 52, Bangkalan, Indonesia \\ ricawijayanti@stkippgri-bkl.ac.id
}

\begin{abstract}
The Covid-19 pandemic provides a change in the paradigm of the world of education. The learning process which is usually carried out face-to-face or offline turns into distance learning or from ng. The selection of learning media is the main factor that an educator must have in carrying out the distance learning process. One of the learning media that will be tested is the quizizz application. This study aims to see the effectiveness of the use of the quizizz application when the school mathematics lecture process was carried out during the Covid-19 pandemic. The effectiveness of this research is viewed from two aspects, namely the motivation and learning outcomes achieved by students. This type of research is a quasi-experimental study with a randomized posttestonly control group design design. The data collection techniques in this study use the test administration technique and the googleform filling technique. The data analysis that will be used is paired sample t-test. Based on the results of research data analysis using the help of the SPSS version 21 application, it shows that the value of Sig. (2-tailed) is smaller than the significant level $(0.000<0.005)$ both in terms of the results of filling out the motivation questionnaire and student learning outcomes. Therefore, in this study it can be concluded that the use of the quizizz application is effective in school mathematics courses in terms of student motivation and learning outcomes.
\end{abstract}

Keywords: Effectiveness, Quizizz Application, School Mathematics, Learning Motivation, Learning Outcomes

\begin{abstract}
Abstrak
Pandemi Covid-19 memberikan perubahan terhadap paradigma dunia pendidikan. Proses pembelajaran yang biasanya dilakukan secara tatap muka atau luringberubah menjadi pembelajaran jarak jauhatau dari $n g$. Pemilihan media pembelajaran menjadi faktor utama yang harus dimiliki oleh seorang pendidik dalam melakukan proses pembelajaran jarak jauh. Salah satu media pembelajaran yang akan diujicobakan adalah aplikasi quizizz.Penelitian ini bertujuan untuk melihat keefektivan penggunaan aplikasi quizizz saat proses perkuliahan matematika sekolah dilakukanpada masa pandemi covid-19. Efektivitas pada penelitian ini ditinjau dari dua aspek yaitu motivasi dan hasil belajar yang dicapai oleh mahasiswa. Jenis penelitian ini adalah penelitian quasi eksperiment dengan model desain Randomized Posttest-Only Control Group Design.Teknik pengambilan data pada penelitian ini menggunakan teknik pemberian tes dan teknik pengisian googleform. Analisis data yang akan digunakan adalah uji paired sample t-test. Berdasarkan hasil analisis data penelitian dengan menggunakan bantuan aplikasi SPSS versi 21, menunjukkan bahwa nilai dari Sig. (2-tailed) lebih kecil dari taraf signifikan $(0,000<0,005)$ baik ditinjau dari hasil pengisian angket motivasi maupun hasil belajar mahasiswa. Oleh karena itu, pada penelitian ini dapat ditarik kesimpulan bahwa penggunaan aplikasi quizizz. efektif digunakan pada mata kuliah matematika sekolah ditinjau dari motivasi dan hasil belajar mahasiswa.
\end{abstract}

Kata kunci: Efektivitas, Aplikasi Quizizz, Matematika Sekolah, Motivasi Belajar, Hasil Belajar

Copyright (c) 2021Rica Wijayanti, Didik Hermanto, Zainudin

$\square$ Corresponding author: Rica Wijayanti

Email Address: ricawijayanti@stkippgri-bkl.ac.id (Jl. Soekarno Hatta No 52, Bangkalan, Indonesia)

Received 19 Januari 2021, Accepted 06 Februari 2021, Published 06 Maret 2021

\section{PENDAHULUAN}

Pandemi Covid-19 yang terjadi di seluruh kawasan Indonesia memberikan dampak perubahan yang besar khususnya di bidang pendidikan. Pendidikan yang awalnya dilakukan secara tatap muka atau secara langsung harus berubah menjadi pembelajaran dari $n g$ atau berbasis online. Adanya perubahan ini membuat para pendidik baik guru maupun dosen harus kreatif dalam memanfaatkan 
media pembelajaran berbasis teknologi yang dapat mempermudah dalam proses penyampaian bahan ajar kepada peserta didik.

Kreatifitas dosen dalam memilih media pembelajaran yang tepat dapat memberikan pengaruh yang besar terhadap motivasi belajar mahasiswa khususnya pada masa pandemic covid-19 yang menggunakan system pembelajaran jarak jauh. Menurut (Anggraini , 2019)faktor yang mempengaruhi motivasi belajar mahasiswa dibagi menjadi dua yaitu faktor internal dan factor eksternal. Faktor internal yang dimaksud adalah faktor yang berasal dari dalam diri mahasiswa seperti minat terhadap bidang ilmu perkuliahan dan orientasi mahasiswa dalam mengikuti pendidikan tinggi. Sedangkan, untuk factor eksternal adalah faktor yang berasal dari luar meliputi cara dosen menyampaikan bahan perkuliahan dan media pembelajaran yang digunakan. Seiring dengan pendapat di atas, hasil penelitian yang dilakukan oleh (Nurhidayah, 2012) juga menunjukkan bahwa semakin tinggi minat belajar dan dukungan belajar dari pihak orang tua, maka semakin tinggi pula motivasi belajar mahasiswa dalam mengikuti perkuliahan.

Hasil penelitian lain yang dilakukan oleh (Rizqi \& Mayasari, 2018) menunjukkan bahwafaktor yang mempengaruhi motivasi belajar ada dua yaitu factor keluarga dan factor sekolah. Diantara kedua faktor tersebut factor sekolah memberikan pengaruh yang lebih dominan. Faktor sekolah dalam hal ini meliputi kemampuan pendidik dalam menyampaikan bahan ajar dan fasilitas yang dimiliki oleh pihak sekolah. Berdasarkan kegiatan observasi awal yang dilakukan peneliti dengan cara mewawancarai beberapa perwakilan dari mahasiswa, diperoleh informasi bahwa 10 dari 12 orang mahasiswa memiliki motivasi yang rendah ketika proses perkuliahan dilakukan oleh dosen tanpa menggunakan media pembelajaran yang menarik selama masa pandemi. Akibatnya, 75\% mahasiswa mengalami ketidaktuntasan hasil belajar pada bab 1 perkuliahan matematika sekolah. Oleh karena iu, penggunaam media pembelajaran memiliki pengaruh yang signifikan terhadap motivasi dan hasil belajar mahasiswa selama pandemi covid. Hal ini sejalan dengan hasil penelitian (Hapnita, Abdullah, Gusmareta, \& Rizal, 2017) yang mengungkapkan bahwa faktor ekternal memiliki pengaruh lebih dominan dibandingkan faktor internal terhadap hasil belajar. Berdasarkan hal tersebut, pada penelitian ini peneliti memfokuskan untuk memberikan perlakuan dengan menggunakan media pembelajaran sebagai factor eksternal yang akan diteliti.

(Rully Charitas Indra Prahmana, Zulkardi, 2012) berpendapat bahwa "Advancement in technology, education and media by using mobile phones, computers, and the internet, has encouraged humans to improve efficiency and effectiveness in their daily activities. In addition, teachers need to develop the right learning strategies to ensure the right skills are inculcated into students". Maksud dari pendapat diatas adalah adanya kemajuan teknologi yang berkembang dengan memanfaatkan handphone, komputer, dan internet telah terbukti dapat mendorong manusia untuk meningkatkan efisiensi dan efektifitas dalam menjalankan aktivitas sehari-hari. Hal ini sangat erat jika dikaitkan dengan permasalahan proses pembelajaran pada masa pandemi covid yang 
mengharuskan setiap pendidik untuk lebih kreatif dalam memanfaatkan teknologi sebagai media pembelajaran yang menarik dan mudah diterima oleh segala kalangan khususnya peserta didik.

Menurut (Tafonao, 2018) media adalah alat yang dapat dipergunakan untuk menyalurkan proses informasi. Peranan media dalam pembelajaran menurut yaitu (1) sebagai penyalur pesan dari pengirim ke penerima; (2) sebagai alat yang membantu peserta didik untuk menjelaskan sesuatu yang disampaikan oleh pendidik; (3) sebagai perantara antara guru dan peserta didik dalam menjalin hubungan yang baik selama proses pembelajaran berlangsung; dan (4) sebagai salah satu metode untuk mengatasi kebosanan peserta didik selama proses pembelajaran.

Seiring dengan pendapat Tafonao diatas, (Smaldino, Lowther, \& Russel, 2011) juga berpendapat bahwa media pembelajaran memiliki peranan yang sangat penting dalam penyampaian informasi saat proses pembelajaran berlangsung. Penggunaan media yang baik sebisa mungkin harus melibatkan spesialis teknologi yang dicocokkan dengan berbagai referensi bahan ajar sehingga dapat digunakan untuk merancang jalannya proses pembelajaran yang akan dilakukan.(Supriyono, 2018) menjelaskan bahwa media pembelajaran sangat penting digunakan untuk meningkatkan minat belajar siswa.

Media pembelajaran yang sudah ada sangat banyak, namun tidak semua media pembelajaran dapat dengan cocok digunakan oleh setiap pendidik pada situasi dan mata pelajaran tertentu. (Santyasa, 2007) menyatakan bahwa "educational media refer to channel of communication that carry message with an instructional purpose. They are usually utilised for the sole purpose of learning and teaching”. Makna yang dapat diambil dari pernyataan tersebut adalah setiap pendidik harus mampu memilih media yang banyak variasinya menyesuaikan dengan materi yang akan diajarkan dan karakteristik dari peserta didik. Hal ini yang menjadi permasalahan utama bagi para pendidik ketika harus memilih media pembelajaran yang paling tepat untuk digunakan pada situasi tertentu.

Secara umum media dibagi menjadi dua macam yaitu media yang berupa alat peraga dan media yang berbasis teknologi. Namun, menurut (O.D, 2014)"educational media such ad print media, non print media and electronic media”. Media yang sering dipakai saat ini adalah media yang berbasis teknologi karena dianggap sebagai media yang populer dan mengikuti tren perkembangan era 4.0. Salah satu media berbasis teknologi yaitu media berbentuk aplikasi yang memanfaatkan teknologi android. Pemanfaatan media pembelajaran berbasis teknologi informasi memiliki peranan yang sangat penting bagi peserta didik (Adam et al., 2015)

Quizizz awalnya digunakan untuk permainan serta hiburan bagi anak-anak yang menyukai tantangan. Namun, akhir-akhir ini peranan aplikasi android ini diubah fungsinya oleh beberapa pendidik sebagai media pembelajaran. Perubahan fungsi dari aplikasi ini sangat membantu para pendidik dalam melakukan evaluasi terhadap proses pembelajaran yang sudah dilakukan di kelas. Menurut hasil penelitian (mei, Ju, \& Adam, 2018)mengungkapkanbahwa "According to testing the implementing of quizizz by researcher during the Arabic skill classroom, found that all students were 
very active to answer the questions which provided by researches, and more concentrated on the topic. And the results of the questioners shows that the students displayed the position attitude for quizizz as a online teaching and assessment tool during the Arabic class". Artinya dari hasil penelitian tersebut menunjukkan bahwa media quizizz dapat membuat peserta didik menjadi aktif dan tertantang untuk menjawab pertanyaan sehingga pendidik akan lebih mudah mengevaluasi proses pembelajaran yang dilakukan.

Hasil penelitian lain yang pernah dilakukan oleh (Aini , 2019) menunjukkan bahwa quizizz dapat dijadikan sebagai salah satu altrnatif media pembelajaran yang kreatif, inovatif, dan menyenangkan sehingga motivasi peserta didik lebih tinggi dan hasil belajar akan menjadi lebih baik. Penggunaan quizizz sebagai media pembelajaran juga dapat meningkatkan konsentrasi belajar peserta didik(Liantoni, Rosetya, Rizkiana, Farida, \& Hermanto, 2018). Penggunaan media pembelajaran quizizz sangatlah mudah dan sederhana. Selain itu, media ini termasuk pada aplikasi android yang kapasitasnyatidakterlalubesarsehinggapenggunatidakmemerlukankuota dan ruangpenyimpanan yang besar ketika mendownload. Sedangkan bagi pendidik sendiri aplikasi ini memiliki fitur yang memudahkan dalam melakukan proses evaluasi pembelajaran, pendidik bias langsung melihat nilai yang diperoleh oleh setiap peserta didik sehingga proses pengambilan evaluasi selanjutnya dapat dilakukan dengan cepat.

Hasil penelitian lainnya dilakukan oleh (Panggabean \& Harahap, 2020) menunjukkan bahwa penggunaan media interaktif quizizz lebih baik dibandingkan tanpa menggunakan media. Selain itu, hasilnya juga menunjukkan bahwa penggunaan media ini berpengaruh sebesar $78 \%$ terhadap hasil belajar mahasiswa. Selain itu, menurut (Wibawa, Astuti, \& Pangestu, 2019) kelebihan penggunaan aplikasi quizizz dalam pembelajaran adalah membuat proses pembelajaran lebih menyenangkan dan memunculkan motivasi serta semangat kembali bagi siswa.

\section{METODE}

Jenis penelitian ini adalah penelitian quasi eksperiment dengan model desain Randomized Posttest-Only Control Group Design. Penelitian dilakukan di STKIP PGRI Bangkalan dengan subyek penelitian adalah mahasiswa pendidikan matematika yang mengikuti perkuliahan matematika sekolah. Efektivitas penggunaan aplikasi quizizz ditinjau dari dua aspek yaitu motivasi dan hasil belajar mahasiswa. Hasil belajar mahasiswa pada penelitian ini hanya difokuskan pada aspek pengetahuan atau kognitif saja sesuai dengan latar belakang penelitian yang dijelaskan di bagian pendahuluan.Metode pengumpulan data yang digunakan dalam penelitian ini adalah metode pemberian angket motivasi dan pemberiantes. Pemberian angket motivasi dilakukan secara daring dengan meminta mahasiswa mengisi googleform yang sudah disediakan. Sedangkan, pemberian tes juga dilakukan dengan cara daring dan diberikan di akhir pembelajaran pada kelas kontrol maupun kelas eksperimen. Analisis data yang akan digunakan menggunakan analisis uji paired sample test dengan bantuan aplikasi SPSS versi 21.0. 


\section{HASIL DAN DISKUSI}

Proses pengambilan data pada penelitian ini dilakukan dengan 2 cara yaitu pemberian angket motivasi dan pemberian tes. Pemberian angket motivasi dilakukan untuk mengetahui keefektivan penggunaan aplikasi quizizz ditinjau dari motivasi belajar mahasiswa. Sedangkan pemberian tes dilakukan untuk mengetahui keefektivan penggunaan aplikasi quizizz ditinjau dari hasil belajar mahasiswa. Pemberian angket maupun pemberian tes dilakukan sebanyak 2 kali yaitu pada kelas kontrol dan kelas eksperimen. Berikut ini hasil dari analisis angket motivasi belajar mahasiswa.

Tabel 1. Hasil Paired Samples Statistics

\begin{tabular}{|c|c|c|c|c|c|}
\hline & & Mean & $\mathrm{N}$ & Std. Deviation & Std. Error Mean \\
\hline \multirow[b]{2}{*}{ Pair 1} & Motivasi kelas kontrol & 59,29 & 14 & 10,163 & 2,716 \\
\hline & $\begin{array}{l}\text { Motivasi kelas } \\
\text { eksperimen }\end{array}$ & 81,07 & 14 & 7,119 & 1,903 \\
\hline
\end{tabular}

Sumber: Aplikasi SPSS v.21

Berdasarkan hasil tabel 1 di atas, maka dapat diketahui bahwa rata-rata motivasi belajar mahasiswa kelas kontrol adalah sebesar 59,29 sedangkan rata-rata motivasi belajar mahasiswa kelas eksperimen 81,07. Jumlah responden atau subyek yang mengisi angket motivasi ini sebanyak 14 mahasiswa untuk masing-masing kelas. Untuk standart devisiasi dari motivasi belajar mahasiswa kelas kontrol adalah 10,163 dengan rata-rata standart eror sebesar 2,716. Sedangkan untuk standart devisiasi dari motivasi belajar mahasiswa kelas eksperimen adalah 7,119 dengan rata-rata standart eror sebesar 1,903. Selanjutnya akan ditampilkan hasil paired samples correlation pada tabel 2 berikut.

Tabel2.Hasil Paired Sample Correlations

\begin{tabular}{|l|l|r|r|r|}
\hline \multicolumn{2}{|l|}{} & $\mathrm{N}$ & \multicolumn{1}{c|}{ Correlation } & \multicolumn{1}{c|}{ Sig. } \\
\hline Pair 1 & $\begin{array}{l}\text { Motivasi kelas kontrol dan kelas } \\
\text { ekperimen }\end{array}$ & 14 &, 702 &, 005 \\
\hline
\end{tabular}

Sumber: Aplikasi SPSS v.21

Tabel di atas menunjukkan bahwa responden yang mengisi angket motivasi adalah sebanyak 14 mahasiswa dengan nilai korelasi sebesar 0,702 dan nilai signifikan sebesar 0,005. Nilai sig < probabilitas 0,05 maka dapat disimpulkan bahwa ada hubungan antara variable motivasi kelas kontrol dan kelas eksperimen yang digunakan. Setelah ditampilkan 2 tabel di atas, selanjutnya akan ditampilkan hasil tabel paired samples test yang akan menunjukkan keefektifan dari penggunaan media aplikasi quizizz ditinjau dari motivasi belajar mahasiswa. 
Tabel 3. Hasil Paired Samples Test

\begin{tabular}{|c|c|c|c|c|c|c|c|c|c|}
\hline & & \multicolumn{5}{|c|}{ Paired Differences } & \multirow[t]{3}{*}{$\mathrm{t}$} & \multirow[t]{3}{*}{$\mathrm{df}$} & \multirow{3}{*}{$\begin{array}{l}\text { Sig. (2- } \\
\text { tailed) }\end{array}$} \\
\hline & & \multirow[t]{2}{*}{ Mean } & \multirow[t]{2}{*}{$\begin{array}{l}\text { Std. } \\
\text { Devia } \\
\text { tion }\end{array}$} & \multirow[t]{2}{*}{$\begin{array}{l}\text { Std. } \\
\text { Error } \\
\text { Mean }\end{array}$} & \multicolumn{2}{|c|}{$\begin{array}{l}\text { 95\% Confidence } \\
\text { Interval of the } \\
\text { Difference }\end{array}$} & & & \\
\hline & & & & & Lower & Upper & & & \\
\hline Pair 1 & $\begin{array}{l}\text { Motivasi } \\
\text { kelas kontrol } \\
\text { - Motivasi } \\
\text { kelas } \\
\text { eksperimen }\end{array}$ & $-21,786$ & 7,234 & 1,933 & $-25,963$ & $-17,609$ & $-11,268$ & 13 & ,000 \\
\hline
\end{tabular}

Sumber: Aplikasi SPSS v.21

Nilai Sig. dari tabel di atas menunjukkan $0,000<0,05$. Artinya, dari hasil tersebut menunjukkan bahwa penggunaan media aplikasi quizizz dikatakan efektif digunakan jika ditinjau dari motivasi belajar mahasiswa. Hasil penelitian ini sejalan dengan hasil penelitian yang pernah dilakukan oleh (Aini , 2019) yang menunjukkan bahwa media pembelajaran quizizz efektif digunakan untuk pembelajaran jenjang pendidikan dasar dan menengah. Penelitian (Purba, 2019) juga mengungkapkan bahwa media quizizz memiliki beberapa kelebihan yaitu membuat siswa senang dan tertantang selama mengerjakan soal-soal yang dilengkapi dengan animasi di aplikasi quizizz.

Hasil penelitian (Wibawa et al., 2019) juga menunjukkan bahwa dengan menggunakan aplikasi quizizz berbasis smartphone sebagai media pembelajaran dapat membuat peserta didik lebih termotivasi dan antusias dalam mengikuti proses pembelajaran. Akibatnya, ketika motivasi meningkat maka peserta didik lebih fokus dan maksimal memanfaatkan smartphone yang dimiliki sebagai media pembelajaran yang menyenangkan dan mempermudah penyampaian konsep.

Penelitian ini melihat keefektivan juga dari hasil belajar mahasiswa sebagai evaluasi bagi dosen pengampu. Seperti halnya pemberian angket, pemberian soal tes juga dilakukan sebanyak 2 kali pada penelitian ini yaitu pada kelas kontrol dan kelas eksperimen. Berikut ini adalah hasil paired samples statistics

Tabel 4. Hasil Paired Samples Statistics

\begin{tabular}{|l|l|r|r|r|r|}
\hline \multicolumn{2}{|l|}{} & \multicolumn{1}{|c|}{ Mean } & \multicolumn{1}{c|}{ N } & \multicolumn{1}{c|}{$\begin{array}{c}\text { Std. } \\
\text { Deviation }\end{array}$} & \multicolumn{1}{c|}{$\begin{array}{c}\text { Std. Error } \\
\text { Mean }\end{array}$} \\
\hline \multirow{3}{*}{ Pair 1 } & Kelas Kontrol & 62,14 & 14 & 8,484 & 2,267 \\
\cline { 2 - 6 } & $\begin{array}{l}\text { Kelas } \\
\text { Eksperimen }\end{array}$ & 78,93 & 14 & 5,255 & 1,404 \\
\hline
\end{tabular}

Sumber: Aplikasi SPSS v.21

Berdasarkan hasil tabel 4 di atas, maka dapat diketahui bahwa rata-rata hasil belajar mahasiswa kelas kontrol adalah sebesar 62,14 sedangkan rata-rata hasil belajar mahasiswa kelas eksperimen 
adalah sebesar 78,93 Jumlah subyek kelas kontrol dan kelas eksperimen asing-masing adalah 14 mahasiswa Untuk standart devisiasi dari hasil belajar mahasiswa kelas konrol adalah 8,484 dengan rata-rata standart eror sebesar 2,267. Sedangkan untuk standart devisiasi dari hasil belajar kelas eksperimen adalah 5,255 dengan rata-rata standart eror sebesar 1,404

Selanjutnya akan ditampilkan tabel hasil paired sample correlation untuk mengetahui ada tidaknya keterkaitan antara variabel pertama yaitu posttest kelas kontrol dan variabel kedua yaitu posttest kelas eksperimen. Berikut ini adalah tabel hasil paired sample corelation.

Tabel 5. Hasil Paired Sample Corelation

\begin{tabular}{|l|l|r|r|r|}
\hline \multicolumn{2}{|l|}{} & N & Correlation & \multicolumn{1}{|c|}{ Sig. } \\
\hline Pair 1 & $\begin{array}{l}\text { Posttest kelas kontrol } \\
\text { \& Posttest kelas } \\
\text { eksperimen }\end{array}$ & 14 &, 444 &, 012 \\
\hline
\end{tabular}

Sumber: Aplikasi SPSS v.21

Pada tabel di atas, tampak jelas bahwa nilai korelasi antara posttest kelas kontrol dan posttest kelas eksperimen sebesar 0,444. Sedangkan untuk nilai Sig adalah sebesar 0,12. Artinya, antara posttest kelas kontrol dan posttest kelas eksperimen memiliki keterkaitan. Untuk mengetahui keefektifan dari penggunaan media aplikasi quizizz, maka selanjutnya akan ditunjukkan tabel hasil paired sample test.

Tabel 6. Hasil Paired SamplesTest

\begin{tabular}{|c|c|c|c|c|c|c|c|c|c|}
\hline & \multicolumn{5}{|c|}{ Paired Differences } & \multirow[t]{3}{*}{$\mathrm{t}$} & \multirow[t]{3}{*}{$\mathrm{df}$} & \multirow{3}{*}{$\begin{array}{l}\text { Sig. } \\
\text { (2- } \\
\text { tailed) }\end{array}$} \\
\hline & & \multirow[t]{2}{*}{ Mean } & \multirow[t]{2}{*}{$\begin{array}{l}\text { Std. } \\
\text { Deviati } \\
\text { on }\end{array}$} & \multirow[t]{2}{*}{$\begin{array}{l}\text { Std. } \\
\text { Error } \\
\text { Mean }\end{array}$} & \multicolumn{2}{|c|}{$\begin{array}{l}\text { 95\% Confidence } \\
\text { Interval of the } \\
\text { Difference }\end{array}$} & & & \\
\hline & & & & & Lower & Upper & & & \\
\hline Pair 1 & \begin{tabular}{|l|} 
Kelas \\
Kontrol- \\
Kelas \\
Eksperimen
\end{tabular} & $-16,786$ & 7,748 & 2,071 & $-21,259$ & $-12,312$ & $-8,106$ & 13 & , 000 \\
\hline
\end{tabular}

Sumber: Aplikasi SPSS v.21

Nilai Sig. dari tabel 6 di atas menunjukkan $0,000<0,05$. Artinya, dari hasil tersebut menunjukkan bahwa penggunaan media aplikasi quizizz dikatakan efektif digunakan jika ditinjau dari hasil belajar mahasiswa. Hasil penelitian ini sejalan dengan hasil penelitian yang pernah dilakukan oleh (Sunardi, 2020) yang menunjukkan bahwa penerapan media evaluasi pembelajaran inovatif quizizz memiliki hubungan yang sangat erat kaitannya dalam meningkatkan hasil belajar siswa SMP. Dalam penelitian Sunardi dijelaskan bahwa media evaluasi quizizz memberikan banyak kebermanfaatan terhadap dunia teknologi dan dunia pendidikan. Pada dunia pendidikan media ini dapat meningkatkan motivasi belajar siswa yang pada akhirnya memberikan pengaruh yang baik terhadap hasil belajar siswa. Di samping itu, media ini juga membuat siswa lebih berhati-hati dan lebih teliti dalam menentukan pilihan jawaban. 
Seiring dengan hasil penelitian ini, penelitian yang dilakukan oleh (Siswanto, 2016) juga menunjukkan bahwa terdapat pengaruh yang signifikan dari ketepatan penggunaan model dan media pembelajaran guru terhadap hasil belajar dan motivasi belajar siswa. Menurut(Solikah, 2020) penggunaan aplikasi quizizz memberikan pengaruh positif yang signifikan jika ditinjau dari hasil belajar dan motivasi belajar siswa.Berbeda dengan hasil penelitian ini, penelitian yang dilakukan oleh (Kustiani \& Hariani, 2018) menunjukkan bahwa hasil belajar tidak hanya dipengaruhi oleh penggunaan model dan media pembelajaran melainkan dipengaruhi oleh factor intelegensi yang dimiliki oleh peserta didik.

\section{KESIMPULAN}

Hasil analisis data penelitian ini menunjukkan bahwa penggunaan aplikasi quizizz sebagai media pembelajaran untuk mahasiswa program studi pendidikan matematika dikatakan efektif ditinjau dari 2 aspek yaitu motivasi belajar dan hasil belajar. Hal ini dibuktikan dengan nilai Sig. sebesar 0,000 untuk motivasi belajar dan hasil belajar.

\section{UCAPAN TERIMA KASIH}

Peneliti mengucapkan terima kasih kepada seluruh civitas STKIP PGRI Bangkalan yang telah membantu peneliti memberikan fasilitas sarana dan prasarana sehingga penelitian ini berjalan dengan lancar dan selesai tepat waktu. Selain itu, peneliti juga mengungkapkan terima kasih kepada mahasiswa program studi pendidikan matematika yang sudah bersedia untuk menjadi subyek pada penelitian ini .

\section{REFERENSI}

Adam, S., Kom, S., Msi, M., Syastra, M. T., Kom, S., \& Si, M. (2015). Steffi Adam, S.Kom., M.MSI. Dan Muhammad Taufik Syastra S.Kom., M.SI. 2015. 3(2), 78-90.

Aini , Y. I. (2019). PEMANFAATAN MEDIA PEMBELAJARAN QUIZIZZ UNTUK PEMBELAJARAN JENJANG PENDIDIKAN DASAR DAN MENENGAH DI BENGKULU Oleh: Kependidikan, 2(25), 1-6.

Anggraini , I. S. (2019). MOTIVASI BELAJAR DAN FAKTOR-FAKTOR YANG BERPENGARUH: SEBUAH KAJIAN PADA INTERAKSI PEMBELAJARAN MAHASISWA Irmalia Susi Anggraini *.

Hapnita, W., Abdullah, R., Gusmareta, Y., \& Rizal, F. (2017). FAKTOR INTERNAL DAN EKSTERNAL YANG DOMINAN SISWA KELAS XI TEKNIK GAMBAR BANGUNAN SMK N 1 PADANG TAHUN 2016 / 2017. 5(1).

Kustiani, L., \& Hariani, L. S. (2018). Faktor-Faktor Yang Mempengaruhi Hasil Belajar Siswa. 12(1), 14-22.

Liantoni, F., Rosetya, S., Rizkiana, R., Farida, F., \& Hermanto, L. A. (2018). Peran Teknologi 
Informasi Untuk Peningkatan Kemampuan Siswa SMA dan SMK Dalam Menghadapi $\begin{array}{lllll}\text { Perkembangan } & \text { Era } & \text { Digital. }\end{array}$ https://doi.org/10.26858/publikan.v8i2.5618

mei, S. Y., Ju, S. Y., \& Adam, Z. (2018). Implementing Quizizz as Game Based Learning in the Arabic Classroom. European Journal of Social Sciences Education and Research, 12(1), 208. https://doi.org/10.26417/ejser.v12i1.p208-212

Nurhidayah. (2012). FAKTOR-FAKTOR YANG MEMPENGARUHI MOTIVASI BELAJAR MAHASISWA PROGRAM STUDI PGSD FKIP UNIVERSITAS AHMAD DAHLAN.

O.D, O. (2014). Relevance of Educational Media and Multimedia Technology for Effective Service Delivery in Teaching and Learning Processes. IOSR Journal of Research \& Method in Education (IOSRJRME), 4(2), 48-51. https://doi.org/10.9790/7388-04214851

Panggabean, S., \& Harahap, T. H. (2020). STUDI PENERAPAN MEDIA KUIS INTERAKTIF QUIZIZZ. 6(1), 78-83.

Purba, L. S. L. (2019). Peningkatan Konsentrasi Belajar Mahasiswa Melalui Pemanfaatan Evaluasi Pembelajaran Quizizz Pada Mata Kuliah Kimia Fisika I. Jurnal Dinamika Pendidikan, 12(1), 29. https://doi.org/10.33541/jdp.v12i1.1028

Rizqi, A. A., \& Mayasari, S. (2018). Faktor-Faktor yang Mempengaruhi Motivasi Belajar The Factors That Influence Students 'Learning Motivation. (1).

Rully Charitas Indra Prahmana, Zulkardi, Y. H. (2012). Learning Multiplication Using Indonesian Traditional game in Third Grade. IndoMS. J.M.E, 3(2), 115-132.

Santyasa, I. W. (2007). Landasan Konseptual Media Pembelajaran. Makalah, 1-23.

Siswanto, V. L. P. S. dan B. T. (2016). FAKTOR-FAKTOR YANG MEMPENGARUHI HASIL BELAJAR SISWA PADA PEMBELAJARAN PRAKTIK KELISTRIKAN OTOMOTIF SMK DI KOTA YOGYAKARTA Valiant. Jurnal Pendidikan Vokasi, 6(1), 111-120.

Smaldino, S. E., Lowther, D. L., \& Russel, J. D. (2011). Instructional technology and media for learning: teknologi pembelajaran dan media untuk belajar (IX). Jakarta: Kencana.

Solikah, H. (2020). Pengaruh Penggunaan Media Pembelajaran Interaktif Quizizz terhadap Motivasi dan Hasil Belajar Siswa pada Materi Teks Persuasif Kelas VIII di SMPN 5 Sidoarjo Tahun Pelajaran 2019 / 2020 PENGARUH PENGGUNAAN MEDIA PEMBELAJARAN INTERAKTIF QUIZIZZ TERHADAP MOT.

Sunardi, D. (2020). Hubungan Meningkatnya Hasil Belajar Siswa SMP dengan Penerapan Media Evaluasi Pembelajaran Inovatif Quizizz. (January).

Supriyono. (2018). Pentingnya Media Pembelajaran untuk Meningkatkan Minat Belajar Siswa SD. Edustream : Jurnal Pendidikan Dasar, II(1), 43-48.

Tafonao, T. (2018). PERANAN MEDIA PEMBELAJARAN DALAM MENINGKATKAN THE ROLE OF INSTRUCTIONAL MEDIA TO IMPROVING. Jurnal Komunikasi Pendidikan, 2(2), $103-114$. 
Wibawa, R. P., Astuti, R. I., \& Pangestu, B. A. (2019). Smartphone-Based Application "quizizz" as a Learning Media. Dinamika Pendidikan, 14(2), 244-253. https://doi.org/10.15294/dp.v14i2.23359 